\title{
Incorporation of Antibacterial Natural Extract into Layered Double Hydroxide through Memory Effect for Antibacterial Materials
}

\author{
Hyoung-Jun Kim, Do-Gak Jeung, Jae-Min $\mathrm{Oh}^{\dagger}$
}

Department of Energy and Materials Engineering, Dongguk University-Seoul, Seoul 04620, Korea

\section{금속이중층수산화물의 메모리효과를 이용한 항균 천연소재의 담지 및 항균소재의 개발}

\author{
김형준, 정도각, 오제민 ${ }^{\dagger}$ \\ 동국대학교 융합에너지신소재공학과
}

(Received September 10, 2019; Accepted September 18, 2019)

\begin{abstract}
We prepared hybrids between layered double hydroxide $(L D H)$ and natural plant extract such as Peaonia suffruticosa Andrews (PS) and Peaonia Japonica (PJ) which was confirmed anti-bacterial activity through paper disc diffusion assay. According to X-ray diffractometer, scanning electron microscope, zeta-potential measurement and quantification of extract loading amount in hybrids, we confirmed that similar amount of PS and PJ loaded on interparticle pore of $L D H$ with partial adsorption on surface of $L D H$ through reconstruction process. We also evaluated the bacterial colony forming inhibition of PS extract, PJ extract, PS-LDH and PJ-LDH hybrids against Escherichia coli as gram negative bacterium and Bacillus subtilis as gram positive bacterium, suggesting that both hybrids have enhanced anti-bacterial activity compared with extract itself.
\end{abstract}

Keyword : Layered double hydroxide, reconstruction, hybrid, natural plant extract, anti-bacterial activity

서론

금속(수)산화물과 같은 소재는 자연계에 널리 존재하 며, 인류의 역사와 함께 그 쓰임새와 활용도가 지속적으 로 개발되고 있다. 대표적인 금속(수)산화물은 점토광물
로서 알루미노실리케이트 기반의 화학조성을 갖고 있으 며, 도자기 원료에서부터 외상 치료제 등으로 오랫동안 사용되어 왔다. ${ }^{1}$ 점토 뿐 아니라 황토나 기타 광물질들은 건축소재와 일상생활을 제조하는 원료로 사용되어 왔으 며, 과학적으로 규명할 수 있는 기능 뿐 아니라 과학적 규 
명은 어렵지만 경험적으로 알게 된 다양한 기능성으로 인 하여 인류 역사에서 지속적으로 사용되어 오고 있다. 최 근에는 천연에서 얻을 수 있는 금속(수)산화물을 물리화 학적 성질에 따라 분리하는 기술 뿐 아니라 원하는 물성 을 갖는 형태로 제조할 수 있는 기술 또한 개발되고 있기 때문에 이러한 물질들의 성능은 좀 더 세밀하게 조절될 수 있다. 특히, 최근 수십년간 비약적인 발전을 이루어 온 나노기술에 힘입어 금속(수)산화물의 크기를 조절하거 나, 표면 특성을 제어하고, 다른 조성이나 성질의 물질과 균일하게 혼합하는 일들이 가능하게 되었기에 금속(수) 산화물의 활용도는 더욱더 높아지고 있다.

본 논문에서는 금속이중층수산화물을 이용하여 항균 천연소재를 담지하여 항균소재화하는 연구를 소개하고 자 한다. 다양한 천연 무기계 소재 중 특별히 금속이중층 수산화물에 관심을 갖는 가장 큰 이유는 이 물질이 2 차원 의 비등방적 구조를 갖고 있으며, 적층 구조를 이루는 나 노층의 두께가 여타 알려진 물질에 비해서 매우 얇고, 준 안정 구조(meta-stable structure) 때문에 여러가지 반 응성에 대한 가능성이 있기 때문이다. ${ }^{2}$

광물학적 관점에서 금속이중층수산화물은 수산화마그 네슘 $\left(\mathrm{Mg}(\mathrm{OH})_{2}\right)$ 인 브루사이트 구조에서부터 시작한다. 브루사이트는 $\mathrm{D}_{4} \mathrm{~h}$ 점군 대칭을 갖는 $\mathrm{Mg}(\mathrm{OH})_{6}$ 팔면체들이 모서리를 공유하면서 2차원으로 펼쳐진 구조를 갖고 있 다. ${ }^{3-5}$ 이는 암염 구조에서 입방조밀쌓임된 팔면체들이 한 층 건너 하나씩 빠진 것과 같고 결정학적으로는 $\mathrm{CdI}_{2}$ 구조에 가깝다. 브루사이트는 $\mathrm{Mg}(\mathrm{OH})_{2}$ 로 이루어진 얇은 층들이 수소 결합에 의하여 강하게 결합되어 있기 때문에 실제로는 2 차원 성질보다는 3 차원 성질을 띠는 것에 가 깝다. 이러한 브루사이트에서 일부 $\mathrm{Mg}^{2+}$ 가 좀 더 높은 산 화수를 갖는 금속(예를 들어 $\mathrm{Al}^{3+}$ )로 치환되면, 전체 구조 는 일정하게 유지된 상태에서 층 구조에 양전하가 하전된 다. 양으로 하전된 층들은 더 이상 수소결합으로 강하게 결속되지 못하므로 층간에 음이온을 존재시켜 정전기적 인력으로 안정화된다. 층간의 음이온은 강한 결합으로 속 박된 것이 아니기 때문에 외부의 음이온 세기가 커지면 다른 이온으로 교환될 수 있다. ${ }^{6-9}$

이렇게 생성된 물질이 금속이중층수산화물(layered double hydroxide: $\mathrm{LDH}$ )이며, 자연계에서는 하이드로 탈사이트 $\left(\mathrm{Mg}_{6} \mathrm{Al}_{2}(\mathrm{OH})_{16} \cdot \mathrm{H}_{2} \mathrm{O}\right)$ 형태로 많이 발견된다. ${ }^{4,5}$ 하이드로탈사이트 외에도 다양한 금속양이온과 층간 음이온들이 금속이중층수산화물을 이룰 수 있는데, 이 물 질의 일반적인 화학식은 $\mathrm{M}(\mathrm{II})_{1-\mathrm{x}} \mathrm{M}(\mathrm{III})_{\mathrm{x}}(\mathrm{OH})_{2}\left(\mathrm{~A}^{\mathrm{n}-}\right)$ $\mathrm{x} / \mathrm{n} \cdot \mathrm{mH}_{2} \mathrm{O}(0<\mathrm{x}\langle 1, \mathrm{n}-$ :음이온의 전하량, $\mathrm{m}$ 은 결정수 $)$ 로 나타내어진다. $\mathrm{x}$ 의 값은 0 에서 1 사이로 이야기되고 있으 나, 실제 2 가 금속과 3 가 금속의 비율(M(II)/M(III))은 $1 / 1 \sim 5 / 1$ 사이 정도로 한정되어 보고되고 있다. 3 가 양이 온이 $1 / 1$ 비율보다 더 높아지게 되면 층이 갖는 양이온의 전하량이 너무 높아지게 되어 안정한 적층구조를 이룰 수 없게 되고, 3 가 이온의 비율이 $5 / 1$ 보다 더 낮아지면 층의 중간중간에 브루사이트와 같은 지역들이 생성되기 때문 에 단일상의 금속이중층수산화물로 존재하기 어렵다.

금속이중층수산화물은 기본적으로 브루사이트 $\left(\mathrm{Mg}(\mathrm{OH})_{2}\right)$ 나 깁사이트 $\left(\mathrm{Al}(\mathrm{OH})_{3}\right)$ 와 같은 금속수산화물 팔면체를 기본으로 하는 단위이며, 이러한 단위체들은 점 토(clay)를 이루는 기본단위와 유사하기 때문에 점토계열 물질로 분류된다. 다만, 점토들은 대체로 층전하를 띠지 않거나, 음의 층전하를 띠고 층간에 양이온 $\left(\mathrm{Na}^{+}, \mathrm{K}^{+}, \mathrm{Ca}^{2+}\right.$ 등)을 포함하고 있는 반면, 금속이중층수산화물은 양의 층전하를 띠고 층간에 음이온을 포함하고 있기 때문에 종 종 음이온성 점토라고 불리기도 한다. ${ }^{1,4}$ 잘 알려진 점토 화합물인 몬트모릴로나이트(montmorillonite)와 비교 할 때 금속이중층수산화물은 층전하밀도가 훨씬 높고, 층 의 두께가 더 얇으며, 산성 조건에서 쉽게 용해되는 등 물 리화학적 성질이 상이하다. 이러한 물리화학적 성질에 의 하여 금속이중층수산화물의 응용성이 확장될 수 있다.

금속이중층수산화물의 유용한 특성 중 하나는 실리케 이트를 포함하지 않는 구조이되 다양한 2 가와 3 가 금속 의 조합으로 유사한 골격 구조를 만들 수 있다는 점이다. 이 특성은 동일한 구조 내에서 다양한 화학적 성질을 생 성해 낼 수 있다는 장점이 있으며, 특히 촉매 특성을 갖는 전이금속 $\left(\mathrm{Ni}^{2+}, \mathrm{Fe}^{2+} / \mathrm{Fe}^{3+}, \mathrm{Co}^{2+}\right.$ 등 $)$ 을 골격구조에 포함시 킬 수 있다는 점에서 응용성이 높다. 금속이중층수산화물 의 층간 음이온은 정전기적으로 안정화되어 있으나, 외부 에 더 높은 이온세기를 갖는 음이온들이 농도구배를 통해 
접근해 오면 쉽게 이온교환으로 치환될 수 있다. 그렇기 때문에, 금속이중층수산화물 내 존재하는 음이온은 층간 삽입 반응에 의해 가역적으로 치환될 수 있고, 보고된 바 에 따르면, 층간 이온으로 존재 가능한 것들은 무기산 $\left(\mathrm{Cl}^{-}, \mathrm{NO}_{3}{ }^{-}, \mathrm{SO}_{4}{ }^{2-}, \mathrm{CO}_{3}{ }^{2-}\right.$ 등 $)$, 유기산 $\left(\mathrm{CH}_{3} \mathrm{COO}^{-}, \mathrm{C}_{3} \mathrm{H}_{5} \mathrm{O}\right.$ $(\mathrm{COO})_{3}{ }^{3-},\left(\mathrm{CH}_{2}\right)_{2}(\mathrm{COO})_{2}{ }^{2-}$ 등), 쯔비터이온, 비타민 분자, 음이온성 약물분자, 폴리페놀, 긴 사슬을 갖는 계면활성 제, 음이온성 고분자, DNA 등으로 매우 다양하게 확장될 수 있다. ${ }^{9-18}$ 특히 분자의 부피가 큰 고분자들은 층간에 규 칙적으로 배열하는 층간 삽입 반응을 통해 존재할 수도 있지만, 카드집구조(house-of-cards structure)와 같 은 형태로도 존재할 수 있다. 어떤 형태로 존재하는지의 위치와는 상관없이 금속수산화물 층에 의해 담지된 고분 자와 유기물들은 외부의 물리 · 화학 · 생물학적 공격에 대해 안정성을 확보할 수 있다. 금속이중층수산화물에 의 해 안정화된 분자들의 열분해 온도가 높아진다던지, ${ }^{19-21}$ 산성 조건에서 DNA 분자들의 분해가 더뎌진다던지, ${ }^{22,23}$ 혹은 DNA 분해 효소에 의한 공격에 대해 안정성을 확보 한다던지 18,24 하는 현상들이 다수 보고된 바 있다.

금속이중층수산화물에 대한 응용 연구는 오랫동안 촉 매연구 관점에서 주로 진행되어 왔다. 금속이중층수산화 물의 층간에 특정 배위화합물을 고정시키면 이질상 촉매 로서의 역할을 할 수 있고, ${ }^{25,26}$ 금속이중층수산화물을 열 처리하면 혼합금속산화물이 생성되면서 금속의 촉매 성 질이 두드러지기 때문에 그 자체로서도 촉매의 성능을 갖 는다. ${ }^{26-28}$ 그러나, 최근 20 년동안은 상기 문단에서 설명 한 바와 같이 불안정한 유기물이 금속이중층수산화물 내 에 담지될 수 있고, 이러한 유기물의 종류가 생물학적 활 성을 지니는 물질까지 포함할 수 있다는 연구가 보고된 ${ }^{14}$ 22, 29, 30 이래로 생물의학적 응용 연구 또한 큰 관심을 갖 고 있다.

금속이중층수산화물을 생물의학적으로 응용하는 데 있어서의 두가지 핵심사항은 얼마나 다양한 생리활성종 을 담지할 수 있느냐와 얼마나 높은 안정성을 추구할 수 있느냐이다. 후자의 경우 여러 문헌에서 안정화에 대한 가능성이 타진되었지만, 전자의 경우 담지될 대상 물질의 물리화학적 특성에 따라 담지 가능성의 변수가 많이 존재
한다. 특히 2 차원 층상형 구조들의 적층과 카드집 구조에 의해 얼마나 다양한 생리활성종들이 담지될 수 있는지를 확인하기 위해서는 그에 맞는 전략이 필요하다.

이에 본 연구진은 기존의 단순한 이온교환법 외에 메모 리 효과를 이용한 천연소재의 담지를 연구하고자 하였다. 약용 식물들의 추출물들은 다양한 치료능을 갖고 있고, 이는 이미 한의학과 서양의학에서도 잘 확인될 수 있는 사실이다. 다만, 추출물들은 너무나도 다양한 화학종을 갖고 있기 때문에 생리활성종들을 분획하는 것이 매우 어 렵고, 추출물에 존재하는 다양한 분자들을 하나의 매트릭 스에 효율적으로 담지하는 것 역시 어렵다. 그러나, 금속 이중층수산화물이 갖는 메모리 효과는 그 특수성 때문에 다양한 화학종을 동시에 담지할 가능성을 갖고 있다. 금 속이중층수산화물을 적절한 온도에서 가열하면 층을 이 루고 있는 수산화기에서 탈수반응이 일어나고 층간에 존 재하는 이온들은 기화된다. ${ }^{31,}{ }^{32}$ 예컨대. $\mathrm{Mg}_{6} \mathrm{Al}_{2}$ $(\mathrm{OH})_{16} \cdot \mathrm{H}_{2} \mathrm{O}$ 의 화학식을 갖는 금속이중층수산화물을 400- $600^{\circ} \mathrm{C}$ 정도의 온도에서 하소시키면 $\mathrm{Mg}_{6} \mathrm{Al}_{2} \mathrm{O}_{9}$ 의 화학식을 갖는 금속산화물이 된다. 이 물질은 분자 수준 에서 볼 때 $\mathrm{MgO}$ 결정자들이 미세하게 생성되고, 이들 사 이사이에 $\mathrm{Al}$ 이 가교화된 것처럼 존재하고 있다. 이 물질 은 물분자의 존재하에 다시 수화되어 멕시너라이트 (mexinerite)가 되고, ${ }^{33,34}$ 이 반응 중에 적절한 음이온이 존재하면 금속이중층수산화물의 적층구조로 돌아온 다. ${ }^{35,36}$ 금속이중층수산화물은 반복된 탈수-수화 반응에 서 금속이중층수산화물-혼합산화물-금속이중층수산화 물의 상변화를 반복할 수 있기 때문에 이를 메모리 효과 라고 일컫는다. ${ }^{37}$ 중요한 점은 메모리 효과에 의해 금속이 중층수산화물이 원래의 구조를 회복할 때 물리적인 성상 은 변화할 수 있는데, 주로 매끈한 층상형 성상에서 표면 이 울퉁불퉁한 모래장미(sandrose) 성상으로 변화하고, 이 때의 모래장미 구조는 카드집 구조와 유사한 형태를 띠게 된다. 본 연구진은 이러한 변화에 착안하여 하소된 금속이중층수산화물, 즉 혼합금속산화물을 천연 추출물 존재하에 금속이중층수산화물 구조로 재건하였으며, 추 출물 내에 존재하는 음이온들과 대기 중에서 공급받는 탄 산이온들로 원래의 구조가 재건될 때 입자들이 만들어 내 
는 카드집 구조 사이사이에 크기가 큰 추출물 성분들이 담지될 것이라 판단하였다. 본 연구에서는 항균성을 갖는 천연추출물을 금속이중층수산화물에 담지하여 그 항균 성능이 유지되거나 증가되는 현상을 관찰하였으며, 이를 통해 항균소재화에서 금속이중층수산화물의 역할과 잠 재력을 타진하고자 하였다.

\section{2. 재료 및 방법}

\section{1. 재료 및 시약}

질산마그네슘수화물 $\left(\mathrm{Mg}\left(\mathrm{NO}_{3}\right)_{2} \cdot \mathrm{H}_{2} \mathrm{O}\right)$, 질산알루미늄 수화물 $\left(\mathrm{Al}\left(\mathrm{NO}_{3}\right)_{3} \cdot \mathrm{H}_{2} \mathrm{O}\right)$ 과 탄산수소나트륨 $\left(\mathrm{NaHCO}_{3}\right)$ 은 Sigma-Aldrich Co. LLC. (St. Louis, MO, USA)에서 구입하였다. 수산화나트륨 $(\mathrm{NaOH})$ 은 대정화금에서 Nutrient broth와 nutrient agar는 Merck KGaA (Darmstadt, Germany)에서 구매하여 추가적인 정제과 정 없이 사용하였다. 목단피(Paeonia suffruticosa Andrews)와 백작약(Peaonia japonica) 추출물은 건조 한 추출물 $50 \mathrm{~g}$ 을 분쇄한 후 $100^{\circ} \mathrm{C}$ 증류수에서 90 분간 열수 추출하였다. 열수추출한 목단피와 백작약 열수추출 물에서 증류수를 진공 증발기를 이용하여 증발시킨 후 열 수추출물 분말을 확보하였다.

\section{2. 추출물의 항균성 평가}

추출물에 항균성이 있는지 여부를 확인하기 위하여, 그 람 음성균인 Escherichia coli (E.coli)와 그람 양성균인 (Bacillus subtilis(B.subtilis) 두 균주에서 paper disc에 의한 한천배지확산법을 이용하여 평가하였다. 평판배지 에서 배양된 두 균주에서 2 3의 colony를 취해 nutrient broth에 접종하고, $37^{\circ} \mathrm{C}$ 에서 $180 \mathrm{rpm}$ 으로 24 시간 동안 배양하여 균을 활성화 시켰다. 준비된 균 배양액을 자외 선흡광광도계(UV-vis spectrometer, Biowave 2, Biochrom, Cambridge, UK)를 이용하여 $595 \mathrm{~nm}$ 에서 흡광도를 측정하여 흡광도가 0.5 가 되도록 균 희석액을 준비하였다. (E. coli는 1.0 으로 균을 희석한다.) 농도를 조절한 균을 agar plate에 멸균된 도말봉을 이용하여 균 희석액을 균일하게 plate 표면에 도말하였다. $8 \mathrm{~mm}$ 의 paper disc를 일정간격으로 plate 위에 올려놓은 후, $\operatorname{disc}$ 에 $0.25 \%, 0.5 \%, 1.0 \%, 2.0 \%$ 로 녹인 목단피와 백작 약 열수 추출물을 $50 \mu$ 씩 떨어뜨린 후, 충분히 흡수되도 록 10 분간 방치하였다. 시료 처리가 끝난 plate를 24 시간 동안 $37^{\circ} \mathrm{C}$ 배양기에 넣어 배양하여 생성된 미생물 생장 억제환의 직경을 측정하였다.

\section{3. 수열합성을 통한 금속이중층수산화물 전구체 및 금속산화물 중간체 합성}

균일한 입자 크기와 형태를 갖는 $\mathrm{Mg}$ 과 $\mathrm{Al}$ 금속 조성의 금속이중층수산화물 전구체는 이전 연구를 참고한 수열 합성 조건으로 제조하였다. ${ }^{38} 0.3 \mathrm{M}$ 질산마그네슘수화물 $\left(\mathrm{Mg}\left(\mathrm{NO}_{3}\right)_{2} \cdot \mathrm{H}_{2} \mathrm{O}\right)$ 와 $\quad 0.15 \quad \mathrm{M}$ 질산알루미늄수화물 $\left(\mathrm{Al}\left(\mathrm{NO}_{3}\right)_{3} \cdot \mathrm{H}_{2} \mathrm{O}\right)$ 혼합용액 $200 \mathrm{~mL}$ 를 제조하였다. 제조 한 마그네슘과 알루미늄 이온 혼합용액을 $0.91 \mathrm{M}$ 수산화 나트륨 $(\mathrm{NaOH}) / 0.67 \mathrm{M}$ 탄산수소나트륨 $\left(\mathrm{NaHCO}_{3}\right)$ 용액 을 이용하여 금속이온 혼합용액의 $\mathrm{pH}$ 가 9.5 가 될 때까지 적정하였다. 염기와 탄산 $\left(\mathrm{CO}_{3}{ }^{2-}\right)$ 음이온 혼합용액의 적정 으로 생성된 현탁액을 수열합성용기로 옮긴 후, 수열합성 용기를 $150^{\circ} \mathrm{C}$ 오븐에 넣어 48 시간 동안 반응하였다. 48 시간 후 현탁액의 침전물을 원심분리를 통하여 얻은 후, 증류수를 이용하여 3 회 세척하고 동결건조를 통해 분말 을 확보하였다.

재건법 방법으로 추출물과 금속이중층수산화물 하이 브리드를 합성하기 위하여, 합성한 금속이중층수산화물 전구체를 $400^{\circ} \mathrm{C}$ 에서 9 시간 동안 하소하여 금속산화물 중 간체를 확보하였다.

\section{4. 목단피-금속이중층수산화물과 백작약-금속 이중층수산화물 하이브리드 합성}

목단피 열수추출물과 백작약 열수 추출물을 금속이중 층수산화물과 재건법 방법을 이용하여 하이브리드를 제 조하였다. 목단피 열수추출물과 백작약 열수추출물 분말 을 각각 증류수에 녹여 $6.6 \mathrm{mg} / \mathrm{mL}$ 농도의 목단피 열수 추출물과 $8.9 \mathrm{mg} / \mathrm{mL}$ 의 백작약 열수추출물 용액을 제조 하였다. 금속산화물 중간체 $0.7 \mathrm{~g}$ 과 동일한 고형분 무게 에 해당하는 부피의 목단피 $(106.424 \mathrm{~mL})$ 또는 백작약 
열수추출물 $(78.888 \mathrm{~mL})$ 을 둥근바닥플라스크에 넣고 질 소가스 조건하에 차광한 상태로 24 시간동안 반응하였다. 최종적으로 얻어진 2 종류의 하이브리드 현탁액에서 원 심분리를 통하여 고형분을 분리하고, 탈이산화탄소 (decarbonated water) 증류수를 이용하여 확보한 고형 분을 2 회 세척하여 동결건조 하였다.

\section{5. 추출물-금속이중층수산화물 내 추출물 함량 결정}

목단피-금속이중층수산화물 및 백작약-금속이중층수 산화물 하이브리드에 담지된 추출물의 함량을 결정하기 위하여 건조중량법을 사용하였다. 추출물-금속이중층수 산화물 합성과정에서 하이브리드 현탁액을 원심분리 후 얻은 상층액과 세척 후 얻은 상층액을 모아 하이브리드에 담지된 추출물 함량을 결정하였다. 빈 바이알의 무게를 측정한 후 $1 \mathrm{~mL}$ 의 현탁액 원심분리 후 얻은 상층액과 세 척 후 얻은 상층액을 빈 바이알에 넣고 가열기에서 $200^{\circ} \mathrm{C}$ 로 가열하여 증류수를 증발시켰다. 증류수가 증발된 바이 알의 무게를 측정하고 빈 바이알의 무게를 빼서 원심분리 상층액 또는 세척 후 얻은 상층액 $1 \mathrm{~mL}$ 에 포함되어 있는 고형분의 무게를 구하고 원심분리 상층액과 세척 후 얻은 상층액의 부피를 적용하여 반응 후 남은 고형분의 무게를 구하였다. 반응 초기에 넣어준 추출물 고형분 무게에서 건조중량법을 통해 구한 반응 후 남은 고형분의 무게를 빼서 얻은 담지된 추출물 고형분 무게와 추출물-금속이 중층수산화물 하이브리드의 무게로 추출물-금속이중층 수산화물 내 추출물 함량을 결정하였다.

\section{6. 추출물-금속이중층수산화물의 특성화}

목단피-금속이중층수산화물 및 백작약-금속이중층수 산화물 분말의 결정구조 변화를 확인하기 위하여, $\mathrm{X}$-선 회절분석을 D2 Phaser (Bruker AXS GmbH, Karlsruhe, Germany)를 이용하여 수행하였다. 금속이 중층수산화물 전구체, 금속수산화물 중간체, 목단피-금 속이중층수산화물 및 백작약-금속이중층수산화물 하이 브리드 분말의 $\mathrm{X}$-선 회절패턴은 $5^{\circ}$ 에서 $80^{\circ}$ 의 2 theta 범 위에서 0.5 초당 $0.02^{\circ}$ 의 증가비율로 측정을 진행하였다. 금속이중층수산화물 전구체와 추출물-금속이중층수산
화물 하이브리드의 입자 크기 및 형태 변화를 주사전자현 미경(Scanning electron microscope, Quanta 250 FEG, FEI, Hilsboro, OR, USA)을 이용하여 관찰하였 다. 분말 형태의 각 샘플을 카본테이프가 부착된 홀더에 접착한 후 샘플 표면을 백금/팔라듐 $(\mathrm{Pt} / \mathrm{Pd})$ 을 이용하여 60 초간 코팅하였으며, $30 \mathrm{kV}$ 의 가속전압으로 이미지를 측정하였다. 추출물과 금속이중층수산화물의 재건법을 이용한 하이브리드화 전과 후 금속이중층수산화물 입자 의 표면전하를 평가하기 위하여 제타전위(Zetapotential, ELSZ-1000, Otsuka, Kyoto, Japan)를 측 정하였다. 금속이중층수산화물과 목단피 추출물, 백작약 추출물, 목단피-금속이충층수산화물, 백작약-금속이중 층수산화물 하이브리드를 $1.0 \mathrm{mg} / \mathrm{mL}$ 의 농도로 증류수 에 분산한 후, $0.1 \mathrm{M}$ 수산화나트륨 $(\mathrm{NaOH})$ 과 $0.1 \mathrm{M}$ 염 산 $(\mathrm{HCl})$ 용액을 적정하여 용액의 $\mathrm{pH}$ 를 7 로 조절하여 측 정하였으며, 3 회 반복하여 평균값을 확보하였다.

\section{7. 추출물과 추출물-금속이중층수산화물 하이브리 드의 항균성 평가}

추출물과 추출물-금속이중층수산화물 하이브리드의 항균성은 진탕배양 후 형성된 균 군락(bacteria colony) 수를 비교하여 그람 음성균인 E.coli와 그람 양성균인 B.subtilis 두 균주에서 평가하였다. 균 배양액의 흡광도 를 자외선흡광광도계(UV-vis spectrometer, Biowave 2, Biochrom, Cambridge, UK)로 $595 \mathrm{~nm}$ 에서 측정한 후, 균수가 $1 \times 10^{4} \mathrm{CFU} / \mathrm{mL}$ 가 되도록 사용한 배양액으 로 희석하였다. 균 배양액 $1 \mathrm{~mL}$ 에 추출물의 농도가 $1 \%$ 가 되도록 제조한 목단피 추출물, 백작약 추출물, 목단피금속이중층수산화물, 백작약-금속이중층수산화물 하이 브리드를 첨가하여 $37^{\circ} \mathrm{C}$ 배양기에서 $180 \mathrm{rpm}$ 으로 3 시간 동안 균을 배양하였다. 샘플과 함께 배양한 균 배양액을 1000 배 희석한 후, 희석한 균 배양액 $10 \mu \ell$ 를 agar plate 에 떨어뜨린 뒤, 멸균된 도말봉을 이용하여 균이 고르게 퍼질 수 있도록 도말하였다. 균이 도말된 agar plate를 14 시간 동안 $37^{\circ} \mathrm{C}$ 배양기에서 배양한 뒤, 추출물과 추출 물-금속이중층수산화물 하이브리드를 처리한 균의 생성 된 균 군락수를 비교하였다. 이때 샘플을 처리하지 않은 
CERAMIST

특 집 ㅁㅁ 김형준, 정도각, 오제민

균 배양액을 도말한 agar plate의 생성된 균 군락수를 $100 \%$ 로 하여 샘플을 처리한 균배양액에서 생성된 균 군 락 비교하였다.

\section{3. 결과 및 고찰}

본 연구에서 사용된 천연 추출물은 일반적으로 항균성 을 갖고 있다고 알려진 바 있는 목단피와 백작약을 사용 하였다. 이들 약용 식물들을 열수 추출한 추출물이 항균 성을 나태나는지 여부를 확인하기 위하여 paper disc를 이용한 한천배지확산법을 적용하였고, 그람 음성균인 E. coli와 그람 양성균인 B.subtilis에서 각각 항균성을 평 가하였다. Fig. 1은 목단피 및 백작약 열수추출물을 각각 $0.25 \%, 0.5 \%, 1.0 \%, 2.0 \%$ 농도로 처리하였을 때의 항균 성을 평가한 결과이다. 이 실험에 의하여 추출물의 종류 에 따른 항균성 여부 뿐만 아니라 각 추출물의 농도에 따 른 항균성 여부도 확인할 수 있었다. Paper disc를 이용 한 한천배지확산법은 paper disc 주변에 생성된 억제환 의 여부 및 억제환의 크기에 따라서 처리된 물질의 항균 성 여부 및 항균성을 나타내는 농도 범위를 확인할 수 있 는 방법이다.
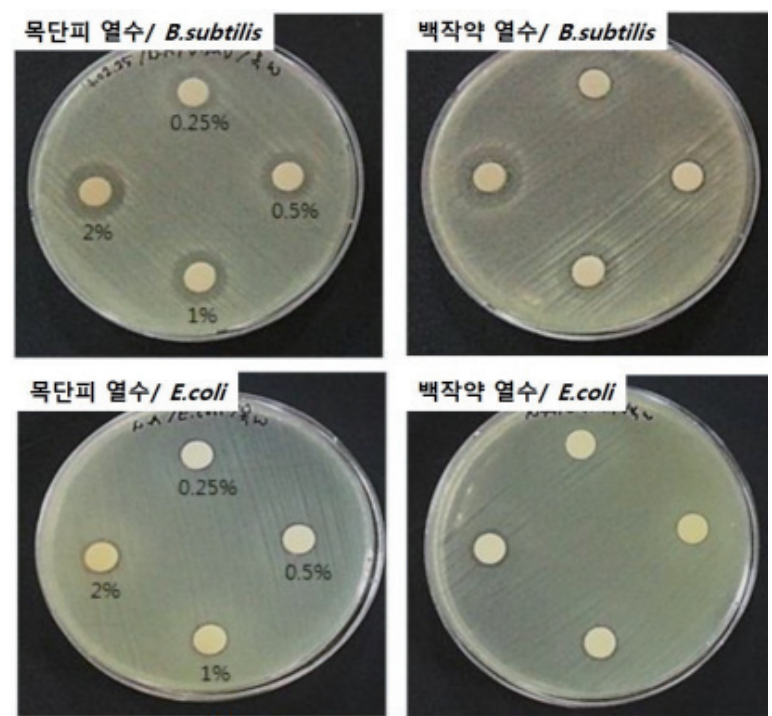

백작약 열수/ E.coli

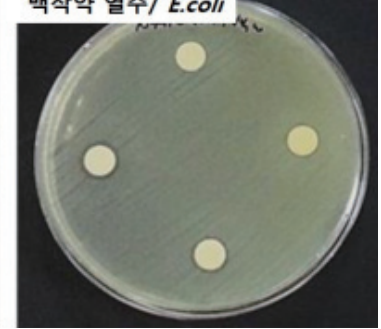

Fig. 1. Paper disc diffusion assay를 통한 목단피 및 백작약 열수추 출물의 항균성 확인
그람 양성균인 B.subtilis에 $0.25 \%, 0.5 \%, 1.0 \%$ 및 $2.0 \%$ 농도의 목단피 열수 추출물을 처리한 경우 각각 $13.2 \mathrm{~mm}, 14.0 \mathrm{~mm}, 14.3 \mathrm{~mm}, 15.5 \mathrm{~mm}$ 의 억제환이 생 성된 것을 확인할 수 있었다. 이 결과를 통하여 목단피 열 수 추출물은 $0.25 \%-2.0 \%$ 농도에서 B. subtilis에 대한 항균성을 보임을 확인할 수 있었고, 농도가 높아질수록 항균성을 나타내는 억제환(inhibition zone)은 그에 비례 하여 커지는 것을 확인할 수 있었다. 백작약 열수 추출물 의 경우 B.subtilis에서 $0.25 \%$ 및 $0.5 \%$ 의 비교적 낮은 농 도에서는 유의미한 정도의 억제환을 관찰할 수 없었으나, 백작약 처리 농도가 $1.0 \%$ 와 $2.0 \%$ 일 경우에는 $9.5 \mathrm{~mm}$ 와 $10.3 \mathrm{~mm}$ 의 억제환을 관찰할 수 있었다. 이 결과에 따 라 백작약 열수추출물은 목단피 열수추출물에 비하여 상 대적으로 높은 농도에서 B.subtilis에 대한 항균능을 갖는 것을 알 수 있다. 그람 음성균인 E.coli에 목단피 열수 추 출물을 처리한 경우에는 $0.25 \%$ 와 $0.5 \%$ 농도에서는 유의 미한 수준의 억제환을 관찰할 수 없었으나, 처리 농도가 $1.0 \%$ 와 $2.0 \%$ 인 경우 $9.25 \mathrm{~mm}$ 와 $10.0 \mathrm{~mm}$ 의 억제환을 관찰할 수 있었다. 목단피 열수추출물은 B.subtilis에 대 해서는 낮은 농도에서도 항균성을 가지고 있으나, E.coli 에 대해서는 그 항균능이 비교적 높은 농도( $1.0 \%$ 이상)에 서 나타남을 알 수 있다. 또한 백작약 열수추출물의 경우 에는 E. coli 균주에서 $0.25 \%$ 농도에서만 억제환을 관찰 할 수 없었고, $0.5 \%, 1.0 \%, 2.0 \%$ 처리 농도에서는 각각 $9.3 \mathrm{~mm}, 9.8 \mathrm{~mm}, 10.8 \mathrm{~mm}$ 크기의 억제환을 관찰할 수 있었다. 백작약 열수추출물의 경우 B.subtilis에서는 높 은 농도에서 항균성을 보였으나, E. coli에 대해서는 상대 적으로 낮은 농도에서도 항균성을 보였다.

이 실험 결과를 좀 더 자세히 살펴보면, 본 연구에 사용 된 목단피 및 백작약 열수 추출물은 각각 그람음성균과 그람양성균에 대해 서로 다른 항균성을 보임을 알 수 있 다. 목단피 열수추출물은 그람양성균(B.subtilis)에 대하 여 비교적 낮은 농도에서도 항균성을 보였으나 그람음성 균(E.coli)에 대해서는 항균성을 위한 최소 농도가 더 높 았다. 백작약 열수추출물은 그람양성균(B.subtilis)에 대 하여서는 항균성을 보이는 농도가 높게 요구되었으나, 그 람음성균(E.coli)에 대해서는 비교적 낮은 농도에서도 항 
균성을 보였다. 이러한 서로 다른 항균성질은 두 종류의 열수추출물에 존재하는 항균 성분의 차이, 그리고 그람양 성균과 그람음성균을 구성하는 세포벽에 존재하는 추가 적인 막의 차이 유무에 따른 것으로 판단된다. 비록 두 가 지 종류의 추출물이 그람양성균 및 그람음성균에 대한 항 균력을 보이는 최소 농도가 조금씩 상이했지만, 목단피 및 백작약 열수추출물 두가지 모두 상당히 낮은 농도 ( 1.0\%)에서부터 항균성의 지표인 억제환을 보였기 때 문에 알려진 바와 마찬가지의 항균성을 확인할 수 있었 다. 이 실험에서 얻어진 항균성의 최소 농도는 추출물 2 종과 그람양성균/그람음성균에 대하여 $1.0 \%$ 로 결정될 수 있었기 때문에, 추후 천연 추출물을 담지한 금속이중 층수산화물의 항균성을 평가할 때 천연 추출물 농도를 최 소 항균성을 보이는 $1.0 \%$ 농도 기준을 결정하였다.

천연 추출물인 목단피 열수추출물과 백작약 열수추출 물을 금속이중층수산화물에 재건법을 이용하여 담지하 는 과정에서 금속이중층수산화물 전구체와 금속산화물 중간체, 그리고 목단피-금속이중층수산화물, 백작약금속이중층수산화물 2 종의 하이브리드가 갖는 결정구조 에 어떠한 변화가 있는지 확인하기 위하여 분말 X-선 회 절분석을 수행하였다. 전구체가 되는 금속이중층수산화 물의 분말 X-선 회절 패턴은 $11.6^{\circ}, 23.4^{\circ}, 34.5^{\circ}, 38.4^{\circ}$, $45.5^{\circ}, 60.7^{\circ}, 62.0^{\circ}$ 위치의 2theta에서 각각 hydrotalcite (Joint Commitee on Powder Diffraction Standards (JCPDS) card No. 14-0191) 결정구조가 갖는 (003), (006), (012), (015), (018), (110), (113) 결정면에 대한 높 은 결정성의 피크를 보여주고 있다(Fig. 2(a)). 본 연구에 사용된 금속이중층수산화물은 공침 과정 이후에 수열합 성 조건에서 결정성장을 유도한 것이기 때문에 상기 밀러 지수 결정면에 대한 높은 결정성은 예측되었던 결과이며, 이전 연구의 문헌에서 나타난 것과 유사한 정도의 결정성 임을 확인할 수 있었다. ${ }^{4,38,39}$ 분말 X-선 회절 패턴에서 결정학적 c 축 방향의 피크인 (003)과 (006) 피크를 통해 구한 d-spacing은 $7.6 \AA$ 으로 탄산이온이 층간의 존재 하는 다른 연구의 경우와 비슷한 d-spacing을 나타내는 것으로 보아, 층간에 탄산이온의 존재를 확인할 수 있었 다. ${ }^{40-42}$ 이 탄산이온은 추후 열처리를 통한 하소 과정에

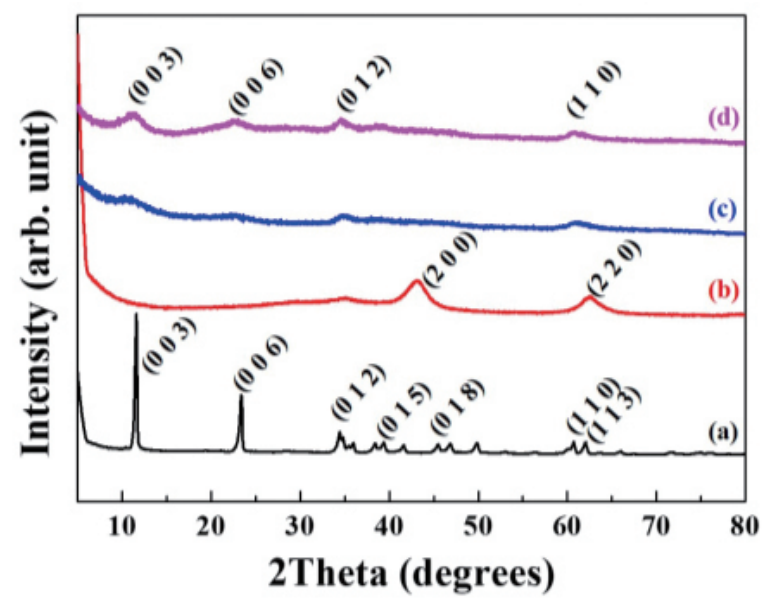

Fig. 2. (a) 전구체 $L D H$, (b) 중간체 $L D O,(c)$ 목단피-LDH(열수) 및 (d) 백작약-LDH(열수) 하이브리드의 X-선 회절패턴

서 이산화탄소로 변환되어 기화될 것이 예상되며, 이 과 정을 통해 금속이중층수산화물의 금속산화물로의 상전 이가 원활이 일어날 수 있을 것이다.

예상한 바와 마찬가지로, 금속이중층수산화물 전구체 를 하소하여 확보한 금속산화물의 분말 X-선 회절 패턴 에서는 기존의 금속이중층수산화물이 갖는 hydrotalcite 의 결정구조가 사라지고, $43.3^{\circ}$ 와 $62.5^{\circ}$ 의 2 theta 위치에 서 산화마그네슘( $\mathrm{MgO})$ 의 periclase (JCPDS card No. 45-0946)의 (200)과 (220) 피크로 결정구조가 변함을 확인할 수 있었다 (Fig. 2(b)). 이러한 결정구조의 변화는 금속이중층수산화물을 $400^{\circ} \mathrm{C}$ 에서 하소하는 과정에서 층 간 음이온인 탄산이온 $\left(\mathrm{CO}_{3}{ }^{2-}\right)$ 과 물분자가 $\mathrm{CO}_{2}$ 와 $\mathrm{H}_{2} \mathrm{O}$ 로 기화되면서 제거되고, 층을 형성하는 금속수산화물에서 수산화기가 제거되어 금속산화물이 되면서 층간구조가 무너지게 되어 이과 같은 결정구조의 변화가 일어난다. ${ }^{43}$ 본 연구에 사용된 금속이중층수산화물은 $\mathrm{Mg}$ 와 $\mathrm{Al}$ 이 2:1 의 비율로 혼합된 조성을 갖고 있는데, 금속이중층수산화 물의 결정구조를 $\mathrm{ab}$-면의 2차원에 그려보면, 육방정계 의 결정구조 내에 $\mathrm{Al}(\mathrm{OH})_{6}$ 팔면체 하나가 $\mathrm{Mg}(\mathrm{OH})_{6}$ 팔면 체 6 개에 의해 둘러싸여 있음을 알 수 있다. 즉, $\mathrm{Mg}(\mathrm{OH})_{6}$ 팔면체들끼리는 서로 연결되어 있지만, $\mathrm{Al}(\mathrm{OH})_{6}$ 팔면체 
간에는 연결성이 없기 때문에, 하소 과정에서 탈수 반응 시 일어나는 결정의 수축시 $\mathrm{MgO}$ 는 생성될 수 있지만, $\mathrm{Al}_{2} \mathrm{O}_{3}$ 의 구조는 생성되기 어렵다. 금속이중층수산화물을 하소하여 얻는 금속산화물에 대한 매우 구체적인 물리화 학적 해석은 어렵지만, 일반적으로 $\mathrm{MgO}$ 의 구조를 갖는 미세한 결정자들이 생성되고, 이들 결정자 사이에 $\mathrm{Al}$ 이 존재하여 결정자들을 연결하여 줄 것으로 예상하고 있 다. ${ }^{44}$ 본 연구진이 이전에 연구한 바에 따르면, $\mathrm{Mg}-\mathrm{Al}$ 조 성을 갖는 금속이중층수산화물을 하소하면, $\mathrm{Al}^{3+}$ 가 6 배 위를 하는 팔면체 자리에서 일부 4 배위 자리로 이행될 수 있다. ${ }^{44}$ 이러한 과정 속에서 $\mathrm{Al}$ 자리는 $\mathrm{Al}_{2} \mathrm{O}_{3}$ 를 생성하기 보다는 $\mathrm{MgO}$ 미세 결정자들을 연결해 주는 역할을 하는 것으로 판단된다.

금속산화물과 목단피 열수추출물을 반응하여 재건법 으로 금속이중층수산화물에 목단피 열수추출물을 담지 한 경우 분말 $\mathrm{X}$-선 회절패턴에서는 $11.2^{\circ}, 22.6^{\circ}, 34.7^{\circ}$ 와 $60.9^{\circ}$ 에서 hydrotalcite의 결정구조에 해당하는 (003), (006), (012), (110) 피크가 회복됨을 확인할 수 있 었다 (Fig. 2(c)), 층상형 구조가 회복된 목단피-금속이 중층수산화물의 d-spacing은 $7.9 \AA$ 으로 탄산이온 $\left(\mathrm{CO}_{3}{ }^{2-}\right)$ 이 층간음이온으로 들어가 있는 것으로 판단되었 다. 비록 전구체가 갖는 $d$-spacing 값인 $7.6 \AA$ 보다 다 소 c-축 방향으로 팽창된 것처럼 보이긴 하지만, 이는 다 른 종류의 층간이온 삽입에 의한 것이 아닌 층간 이온의 수화에 따른 것으로 해석할 수 있다. 따라서, 재건법의 결 과로 금속이중층수산화물의 층간에 목단피 추출물 성분 이 층간삽입된 것이 아니라, 탄산이온이 음이온종으로 층 간에 삽입된 구조로 결정구조가 회복됨을 확인할 수 있었 다. 백작약을 담지한 금속이중층수산화물 하이브리드의 분말 $\mathrm{X}$-선 회절패턴에서도 $11.2^{\circ}, 22.6^{\circ}, 34.5^{\circ}, 60.6^{\circ}$ 에 서 hydrotalcite에 해당하는 (003), (006), (012), (110) 피크를 관찰할 수 있었으며, 층상형 결정구조가 회복됨을 확인할 수 있었다 (Fig. 2(d)). 층간음이온 역시 $\mathrm{d}$-spacing으로 판단컨대, 목단피-금속이중층수산화물 의 경우와 마찬가지로, $7.9 \AA$ 해당하는 $d$-spacing을 보 여주었으며, 백작약 추출물의 포함되어 있는 분자들은 금 속이중층수산화물의 층간에 삽입되지 않은 채, 탄산이온
이 층간에 삽입되었음을 확인하였다. 전구체인 금속이중 층수산화물과 천연 추출물이 담지된 후의 하이브리드는 모두 동일한 hydrotalcite 결정상을 갖고 있으나, 한 가 지 확연히 차이나는 것은 각 결정면에 대한 회절 피크의 크기와 너비이다. 두 시료의 (003) 피크에 대한 c축으로 의 결정성을 비교해 보면, 전구체 금속이중층수산화물의 경우 반치폭 (full width half maximum, FWHM)이 0.26 이며, 목단피-금속이중층수산화물의 반치폭은 4.70 , 백작약-금속이중층수산화물의 반치폭은 2.93 으 로 확인되었다. 이러한 반치폭의 증가는 해당하는 c축의 결정성에 대한 감소를 나타내며, 결정자의 감소를 의미한 다. 천연추출물을 재건법으로 담지한 경우 회복된 금속이 중층수산화물이 c축 방향으로 결정성이 급감하는 것은 이전 연구에서와 동일한 것으로서, 금속이중층수산화물 의 적층된 층의 수가 줄어들거나 무질서한 방향으로 층들 이 쌓여 있기 때문으로 확인되었다. ${ }^{45}$ 금속이중층수산화 물과 같은 2 차원 층상형 화합물은 적층된 층의 숫자가 줄 어들 경우 비표면적이 늘어나고 결정 결함이 늘어나는 경 향을 보인다. 일반적으로 결정의 결함이 늘어나는 것은 물성을 제어하기 어려운 결과를 초래할 수 있으나, 본 연 구에서는 c-축 방향의 결정성 감소, 즉 입자 두께의 감소 가 추출물 담지에 유리한 성질로 작용할 수 있다. 두꺼운 책을 여러권 임의로 배열할 경우 책과 책 사이의 공간이 크게 형성되지 않으나, 두꺼운 책을 얇은 책으로 쪼갠 후 무질서하게 배열하게 되면 책과 책 사이의 공간이 더 많 이 형성될 수 있다. 이와 같은 현상이 금속이중층수산화 물에서도 일어날 수 있는데, 이 때 생성된 입자와 입자사 이의 많은 공간은 다양한 크기를 갖는 천연 추출물 성분 을 담지하는 공간으로 이용될 수 있다. 만약, $\mathrm{c}$-축 방향 으로 두꺼운 전구체 입자가 그대로 재건된다면, 입자와 입자사이의 공간이 충분하지 않아서 추출물 성분을 최대 한 담지할 수 없을 것이다. 특히, 천연 추출물에는 종류 와 성질이 서로 다른 많은 화학종들이 존재하기 때문에 최대한 넓은 공간을 확보하는 것이 중요하다. 일반적으로 대부분의 식물 추출물은 탄화수소계열의 고분자, 약간의 지질, 폴리페놀류의 항산화 성분 등을 가지고 있는데, 이 들은 분자의 크기에서부터 친수성/소수성 성질에 이르기 
까지 그 물성이 서로 다르다. 금속이중층수산화물의 재건 시 생성되는 입자와 입자간의 넓은 공간은 이들을 담지하 는 데 있어서 중요한 역할을 할 것으로 판단된다.

상기의 분말 X-선 회절 패턴에 따르면 전구체의 하소 와 재건에 따라 결정상과 결정성의 변화가 눈에 띄게 예 상된다. 특히, 재건 후 확인되는 결정학적 c-축 방향의 결정성 감소는 성상 측면에서 변화 - 입자형 성상에서 모래장미형 카드집 성상으로의 변화 - 를 예상케 한다. 천연추출물인 목단피 열수추출물과 백작약 열수추출물 을 재건법으로 금속이중층수산화물에 담지하는 과정에 서 일어나는 입자의 크기와 형태의 변화를 좀 더 구체적 으로 관찰하기 위하여 금속이중층수산화물 전구체, 금속 산화물 중간체, 목단피-금속이중층수산화물 및 백작약금속이중층수산화물 하이브리드의 주사전자현미경 (scanning electron microscope) 분석을 수행하였다. 금속이중층수산화물 전구체의 입자는 $222 \pm 32.6 \mathrm{~nm}$ 크기를 가지며 균일한 판상형 입자형태를 가지고 있음을 확인하였다 (Fig. 3(a)). 일반적으로 금속이중층수산화물 을 공침법에 의해 합성하게 되면, 2 차원 비등방성 때문에 결정학적 $\mathrm{ab}$-면 방향의 결정성장이 두드러지며 결과적 으로 종횡비가 상당히 높은 입자가 얻어진다. 그에 비해 본 연구에 사용된 금속이중층수산화물은 수열합성 처리 를 거쳤기 때문에 종횡비가 낮아져 있으며, 결정학적 c축 방향의 결정 성장도 두드러진다. 합성법에 따라 금속 이중층수산화물의 입형이 달라질 수 있음은 이전 연구에 서와 유사한 결과로 확인되었다. ${ }^{38}$ 금속이중층수산화물 을 하소하여 얻은 금속산화물 중간체의 경우 금속이중층 수산화물 전구체와 유사한 입자 크기를 가지고 있으며, 판상형의 입자 형태를 가지고 있음을 확인하였다. 정량적 으로 입자의 $\mathrm{ab}$-면 방향 너비와 두께를 비교해 본 결과 하소 후에는 $a b$-면 방향의 너비는 유사하게 유지되나, $\mathrm{c}$-축 방향의 크기는 작아진 것을 확인할 수 있다. 앞서 기술한 바와 마찬가지로 금속이중층수산화물이 하소되 는 과정에서 층간에 존재하는 탄산이온과 물분자가 $\mathrm{CO}_{2}$ 와 $\mathrm{H}_{2} \mathrm{O}$ 로 기화되어 빠져나가며, 층을 이루는 프레임워크 에서도 탈수 반응이 일어난다. 결정학적으로 $\mathrm{Mg}(\mathrm{OH})_{6}$ 와 $\mathrm{MgO}$ 의 $\mathrm{Mg}-\mathrm{O}$ 거리는 크게 차이나지 않기 때문에, 하소
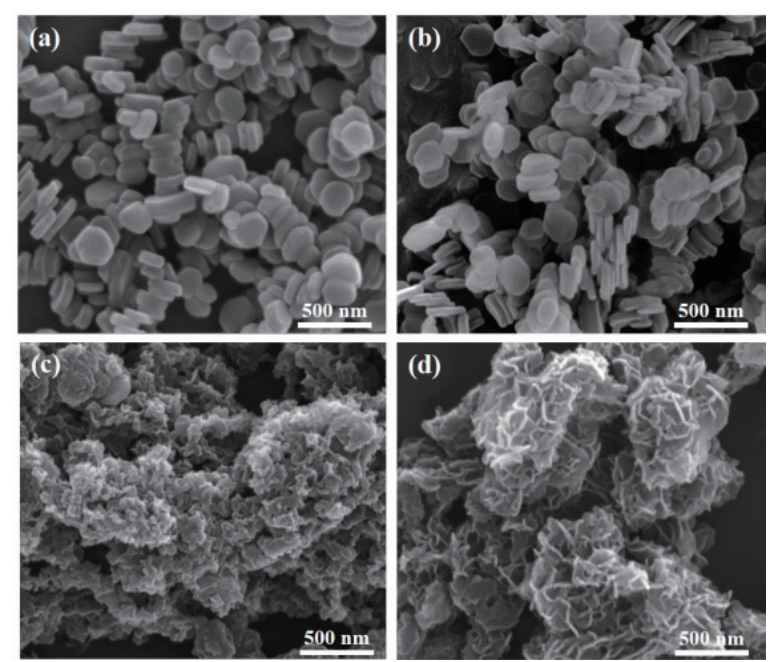

Fig. 3. (a) 전구체 $\mathrm{LDH}$, (b) 중간체 $\mathrm{LDO}$, (c) 목단피-LDH(열수) 및 $(\mathrm{d})$ 백작약-LDH(열수) 하이브리드의 주사전자현미경사진

반응의 결과 생성되는 금속산화물의 $\mathrm{ab}$-면 방향 너비는 크게 줄어들지 않는다. 이에 비해, $\mathrm{c}$-축에서는 층간구조 가 무너지며 $\mathrm{Mg}(\mathrm{OH})_{6}$ 프레임워크가 $\mathrm{MgO}$ 로 변화하며 결 정자간의 연결 - $\mathrm{Al}^{3+}$ 에 의한 $\mathrm{MgO}$ 결정자들의 연결 이 일어나므로 결정의 수축이 큰 폭으로 나타난다(Fig. 3(b)).

목단피-금속이중층수산화물과 백작약-금속이중층수 산화물 하이브리드의 경우 반응 출발물질인 금속산화물 중간체와는 매우 다른 양상을 나타내었다. 두 하이브리드 의 경우 금속이중층수산화물과 금속산화물의 판상형 입 자의 형태가 유지되지 않고, 모래장미 혹은 카드집 형태 의 성상을 나타내는 것을 확인하였는데, 입자의 두께 및 크기 또한 X-선 회절패턴의 c축으로의 결정성 변화에서 관찰된 결과와 부합되게 얇아지는 것을 확인하였다 (Fig. $3(\mathrm{c})-(\mathrm{d})$ ). 재건법에 관한 문헌들을 살펴보면 금속이중층 수산화물의 $c$-축 방향 결정성은 유지되는 경우와 감소되 는 경우가 모두 관찰되는데, 현 시점에서 대한 명확한 설 명은 어렵다. 그러나, 재건과정에 존재하는 화학종이나 이온종에 의해 성상의 차이나 결정성의 차이가 생길 것으 로 판단된다. 예컨대, 재건 과정에서 전구체와 동일한 탄 산이온을 이용한다면, 초기와 거의 유사한 결정성과 성상 이 재현될 수 있다. 그러나, 본 연구에서처럼 다양한 종 
CERAMIST

특 집 ㅃㅁ김형준, 정도각, 오제민

류의 화학종이 존재하고, 일부 고분자나 초분자의 형태를 띠는 화학종이 함께 존재할 경우에는 금속이중층수산화 물의 결정구조 회복 과정에서 다방면의 영향을 받을 것으 로 판단된다. 요컨대, 층상 구조로의 회귀 과정에서 거대 한 초분자/고분자들이 적층을 방해할 수 있기 때문에 전 구체인 금속이중층수산화물의 규칙적인 적층구조가 무 질서한 배열로 나타나거나 층의 일부가 박리화되는 것과 유사한 결과를 보일 것이라고 예상된다. 또한 하이브리드 의 경우 입자들이 카드집 형태의 구조를 이루면서 입자들 사이에 공간을 형성하는데, 목단피-금속이중층수산화물 의 경우 백작약-금속이중층수산화물 하이브리드의 경우 보다 입자의 크기가 작아 보이며, 더 작은 크기의 입자들 때문에 입자들 사이 공간이 더 작을 것으로 판단된다. $\mathrm{X}$-선 회절패턴에서 확인할 수 있었듯이 층간공간에 목 단피 추출물이나 백작약 추출물의 분자가 삽입되는 것이 아닌 탄산이온이 삽입되어 있는 것을 확인하였고, 비교적 크기가 큰 목단피 추출물이나 백작약 추출물의 성분들이 크기에 비교적 제한없이 물질을 담지가 가능한 금속이중 층수산화물 입자들 사이의 공간에 쉽게 담지 되었을 것으 로 판단된다.

목단피와 백작약 열수추출물의 경우 다양한 탄수화물 (carbohydrate), 폴리페놀(polyphenol), 플라보노이드 (flavonoid) 등과 같은 생리활성종을 포함하고 있으며, 이러한 생리활성종에는 다양한 음이온 종들이 존재하여 금속이중층수산화물과 반응 시 양의 표면전하는 갖는 금 속이중층수산화물과 정전기적 인력에 의하여 반응할 수 있는 가능성을 가지게 된다. 따라서 금속이중층수산화물 에 목단피 추출물과 백작약 추출물을 담지 전과 후 금속 이중층수산화물의 표면전하를 비교하는 것은 금속이중
층수산화물의 표면에서 추출물과의 상호작용에 의해 발 생하는 현상을 관찰할 수 있을 것으로 판단되며, 이를 위 해 제타전위(zeta-potential)를 측정하여 표면전하 비교 를 진행하였다 (Table 1). 표면전하는 측정하는 $\mathrm{pH}$ 조건 에 따라 달라지므로, 동일한 $\mathrm{pH} 7$ 조건에서 측정을 진행 하였다. 금속이중층수산화물 전구체의 경우 표면전하는 $35.4 \pm 0.84 \mathrm{mV}$ 로 금속이중층수산화물이 갖는 전형적 인 양의 표면전하를 띄는 것을 확인하였으며, 목단피 열 수출물과 백작약 열수 추출물은 각각 $-18.7 \pm 6.96 \mathrm{mV}$ 와 $-35.6 \pm 2.92 \mathrm{mV}$ 로 음의 표면전하를 갖는 것을 확 인하였다. 이전 연구에서 추출물 내 존재하는 성분들이 입자의 표면과 정전기적 인력에 의해 반응하여 표면을 완 전히 뒤덮고 있다면, 생성된 하이브리드의 표면전하는 금 속이중층수산화물의 표면을 뒤덮고 있는 추출물의 표면 전하와 동일해진다는 것을 확인하였다. ${ }^{46}$ 하지만 목단 피-금속이중층수산화물과 백작약-금속이중층수산화물 의 경우 표면전하가 $7.91 \pm 0.85 \mathrm{mV}$ 와 $21.1 \pm 0.76 \mathrm{mV}$ 로 추출물의 표면전하와는 동일하지 않았으며, 금속이중 층수산화물보다는 음의 표면전하를 띄는 것을 확인할 수 있었다. 이를 통해서 추출물이 재건법을 통하여 금속이중 층수산화물에 담지 될 때, 금속이중층수산화물의 표면을 추출물이 완전히 덮고 있는 것이 아닌 금속이중층수산화 물 입자들이 형성하는 입자사이의 공간에 담지되어 비교 적 금속이중층수산화물의 양의전하를 띄는 부분이 표면 에 노출됨으로써 양의 표면전하를 나타낸다고 판단할 수 있었다. 목단피-금속이중층수산화물이 백작약-금속이 중층수산화물 하이브리드 보다 더 표면전하가 0 에 가까 운 것을 확인할 수 있었는데, 주사전자현미경 분석에서 관찰할 수 있었듯이 목단피-금속이중층수산화물 하이브

Table 1. 목단피-LDH(열수) 및 백작약-LDH(열수) 하이브리드의 제타전위

\begin{tabular}{cc}
\hline Sample name & zeta-potential $(\mathrm{mV})$ \\
\hline 금속이중층수산화물 & $35.4 \pm 0.84$ \\
목단피 열수추출물 & $-18.7 \pm 6.96$ \\
목단피-금속이중층수산화물 하이브리드 & $7.91 \pm 0.85$ \\
백작약 열수추출물 & $-35.6 \pm 2.92$ \\
백작약-금속이중층수산화물 하이브리드 & $21.1 \pm 0.76$ \\
\hline
\end{tabular}


Table 2. 목단피-금속이중충수산화물 및 백작약-금속이중층수산화물 하이브리드 내 추출물 함량

하이브리드 내 추출물 함량 $(\%)$

\begin{tabular}{|l|l|l|r} 
목단피-LDH(열수) & 20.1 & 백작약-LDH(열수) & 20.5 \\
\hline
\end{tabular}

리드가 백작약-금속이중층수산화물 보다 더 작은 입자 사이의 공간을 형성하여 담지 된 추출물 중 입자사이의 공간에 담지 된 양이 더 적고 표면에 흡착되어 있는 추출 물이 더 많기 때문에 더 0 에 가까운 표면전하를 나타내는 것으로 보인다. 그러나 추출물을 담지한 금속이중층수산 화물의 경우 모두 양의 표면전하를 갖기 때문에, 추후 항 균을 위해 사용될 때 음의 표면전하를 갖는 균 표면에 더욱 잘 부착될 수 있어 균에 항균성을 갖는 성분을 더 잘 전달할 수 있을 것으로 판단된다.

금속이중충수산화물 전구체, 금속산화물 중간체, 목단 피-금속이중층수산화물과 백작약-금속이중층수산화물 하이브리드의 X-선 회절패턴, 주사전자현미경 사진, 제 타전위 측정결과를 통해서 Fig. 4에서와 같이 탄산이온 $\left(\mathrm{CO}_{3}{ }^{2-}\right)$ 을 음이온 종으로 포함하는 금속이중층수산화물 이 $400{ }^{\circ} \mathrm{C}$ 에서 하소하여 금속수산화물이 금속산화물로 변형되면서 $\mathrm{MgO}$ 결정이 생성되고, 이러한 결정들 사이 에 $\mathrm{Al}$ 이 가교화된 것처럼 존재하는 형태로 결정구조의 변 화가 생기는 것을 확인할 수 있었다. 또한 이렇게 생성된 금속산화물을 천연추출물과 혼합하여 재건법으로 하이 브리드를 제조할 때, 물분자와 음이온 분자의 존재하여 금속이중층수산화물의 적층구조가 돌아오는 동시에 입 자들 사이의 반응에 의한 카드집 구조가 생성되면서 입자 사이의 공간 또는 표면에 목단피 열수추출물 또는 백작약 열수추출물이 담지되는 것을 확인할 수 있었다.

향후 합성한 천연추출물-금속이중층수산화물 하이브
리드의 항균성을 천연추출물만 처리하였을 때와 비교 평 가하기 위해서, 재건법을 통하여 금속이중층수산화물에 담지한 목단피 및 백작약 열수추출물의 양을 확인할 필요 가 있다. 금속이중층수산화물에 담지된 추출물의 함량은 합성 시에 확보한 상층액에 존재하는 추출물의 양을 건조 중량법으로 구한 후 역산하여 하이브리드에 담지된 추출 물의 함량을 결정하였다. 이와 같은 방법으로 결정한 목 단피-금속이중층수산화물 하이브리드 내 목단피 추출물 의 함량은 $20.1 \%$ 이고, 백작약-금속이중층수산화물 하 이브리드 내 담지된 백작약 추출물의 함량은 $20.5 \%$ 로, 두 추출물이 금속이중층수산화물 내에 동일한 함량으로 담지 되었음을 확인할 수 있었다. 이러한 결과는 주사전 자현미경과 제타전위 측정결과와 연관지어 볼 때, 목단 피-금속이중층수산화물 하이브리드가 비교적 백작약금속이중층수산화물에서보다 작은 크기의 입자사이의 공간을 형성하여 추출물 내 매우 큰 분자의 경우 입자사 이의 공간에 담지되지 못하고 표면에 흡착됨으로써 백작 약-금속이중층수산화물과 비슷한 함량의 추출물을 담지 했음에도 불구하고 더 0에 가까운 표면전하로 수렴한다 는 결과와 잘 부합함을 확인할 수 있었다. 또한, 백작약금속이중층수산화물의 경우 대부분의 추출물이 큰 입자 사이의 공간에 담지되고 일부가 표면에 흡착되어 금속이 중층수산화물의 특성을 띠는 표면이 더욱 외부에 노출됨 으로써 목단피-금속이중층수산화물보다 좀 더 금속이중 층수산화물 전구체에 근접한 양의 표면전하를 나타내는

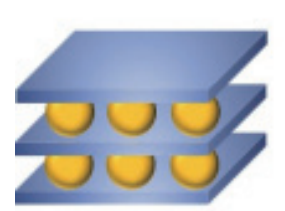

LDH

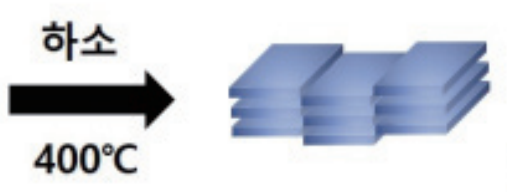

LDO

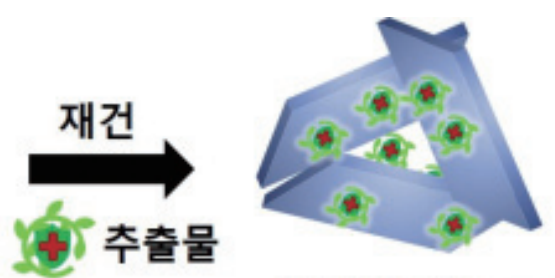

천연추출물-LDH

Fig. 4. 천연추출물과 $L D H$ 의 재건법을 이용한 하이브리드화 모식도 

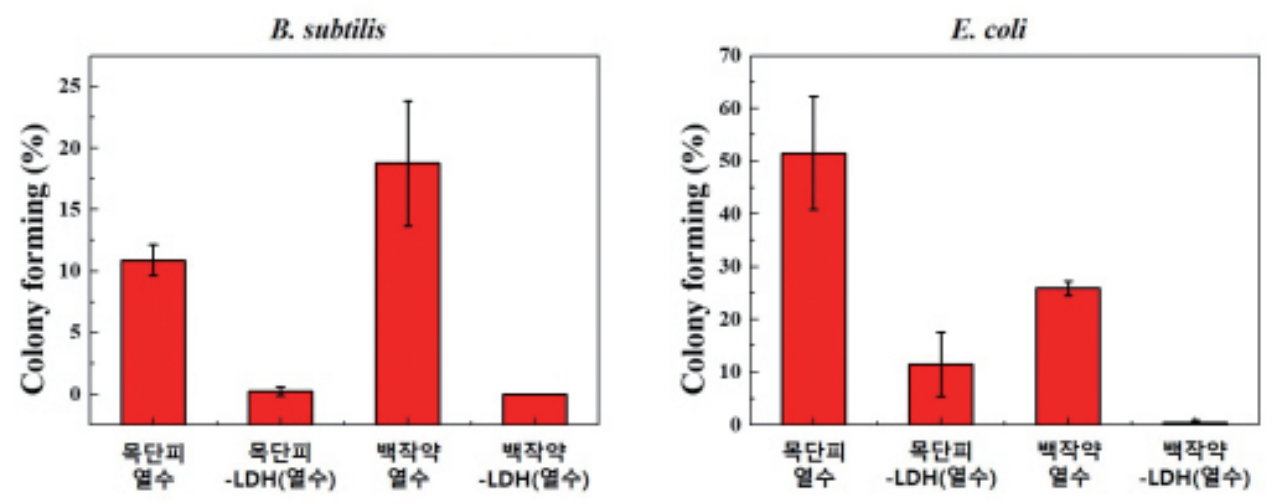

Fig. 5. 목단피 열수, 목단피-LDH(열수), 백작약 열수 및 백작약-LDH(열수)의 항균성 비교

것으로, 이 결과 역시 주사전자현미경, 제타전위 결과와 함량결과는 잘 부합되는 결과임을 확인하였다.

항균성을 띠는 목단피와 백작약 추출물이 금속이중층수 산화물에 담지된 후에 항균성 변화를 관찰하기 위하여 진 탕배양법으로 균주에 시료를 처리하여, 생성된 균 군락 (bacteria colony) 수를 비교하여 평가하였다. 대부분의 세 균은 세균의 세포벽에 얇은 펩티도글리칸 (peptidoglycan) 층과 지질단백질 및 지질당으로 구성된 외부막이 존재하는 그람 음성균과 외부막이 없는 그람 양성균으로 분류될 수 있으며, paper disc를 이용한 한천배지확산법을 통해 추출 물의 항균성을 확인했을 때와 동일한 그람 음성균과 E.coli 와 그람 양성균 B.subtilis 두 균주에서 항균성을 평가하였 다 (Fig. 5). 그람 음성균인 E. coli에 목단피 열수추출물, 목 단피-금속이중층수산화물 하이브리드, 백작약 열수추출 물, 백작약-금속이중층수산화물 하이브리드를 처리한 후 생성되는 균 군락수를 비교한 결과, 시료를 처리하지 않은 대조군에서 생성된 균 군락수를 $100 \%$ 로 하였을 때, 목단피 열수추출물을 처리한 경우 $51.6 \%$ 목단피-금속이중층수산 화물 $11.5 \%$ 의 균 군락이 형성되었음을 확인하였으며, 이 결 과는 동일한 농도의 목단피 열수추출물을 포함하는 샘플을 처리하였을 때 금속이중층수산화물에 추출물을 담지한 경 우 더 항균활성이 증가함을 나타냄을 보여준다. E.coli에 대하여 백작약 열수추출물과 백작약-금속이중층수산화물 을 처리한 경우 대조군에 비하여 $26.0 \%$ 와 $0.38 \%$ 의 균 군 락이 생성되었음을 확인하였으며, 이 역시 금속이중층수산
화물에 추출물을 담지한 경우 항균성이 증가할 수 있음을 나타내었다. 그람 양성균인 B.subtilis 에서는 시료를 처리 하지 않은 대조군과 비교하여 목단피 열수는 $10.9 \%$, 목단 피-금속이중층수산화물 $0.22 \%$ 의 균 군락 형성을 보였으 며, 목단피-금속이중층수산화물에서 더 높은 항균성을 보 였다. 백작약 열수추출물과 백작약-금속이중층수산화물 의 경우에도 시료를 처리하지 않은 대조군에 비교하여 각 각 $18.8 \%$ 와 $0 \%$ 의 균 군락 형성을 보였으며, 백작약-금속 이중층수산화물에서 항균성이 증가함을 확인하였다. 천연 추출물을 재건법으로 금속이중층수산화물에 담지한 모든 시료에서 천연추출물의 의한 세균의 성장이 추출물만을 처 리했을 때보다 더욱 잘 억제됨을 확인할 수 있었다. 이는 항 균성을 보유하고 있는 짚신나물 추출물을 산처리를 통해 비표면적과 기공부피를 개선한 점토광물에 추출물을 담지 한 이전 연구에서와 마찬가지로, 추출물만을 처리한 균의 경우보다 금속이중층수산화물에 추출물을 담지하여 균에 처리하였을 경우 균에 더 잘 부착할 수 가능성을 가지고 있 으며, 이러한 영향으로 하이브리드가 부착된 균의 주위의 항균성을 내는 추출물 성분의 농도가 상대적으로 높아지게 되어 더 높은 항균성을 낼 수 있는 것으로 판단된다. ${ }^{46}$

\section{4. 결론}

본 연구진은 목단피와 백작약 열수추출물이 갖는 항균 성능의 증대를 위하여 금속이중층수산화물의 메모리효 
과를 이용한 재건법을 통하여 금속이중층수산화물 내에 천연추출물을 담지하였다. X-선 회절 분석을 통하여 금 속이중층수산화물이 재건법 과정의 하나인 $400^{\circ} \mathrm{C}$ 에서의 하소 과정 중 층간 음이온과 물분자가 기화되고 금속수산 화물층이 금속산화물로 변화되면서 층상형구조가 무너 지는 것을 확인하였으며, 금속산화물을 목단피 추출물 또 는 백작약 추출물과 반응하였을 때 층간에 대기중의 탄산 이온이 삽입된 채로 층상형 구조가 회복되는 것을 확인하 였다. 또한 주사전자현미경 영상과 표면전하 확인을 위한 제타전위 측정 및 하이브리드 내 동일하게 담지된 추출물 함량을 통하여 하이브리드내 담지된 추출물이 재건과정 에서 금속이중층수산화물 입자들이 형성하는 입자사이 의 공간 및 입자의 표면에 담지되는 것을 확인하였다. 동 일한 추출물 함량의 추출물 자체와 두 가지 하이브리드를 그람 음성균인 E.coli와 그람 양성균인 B.subtilis에 처리 하여 진탕배양법으로 항균성능을 비교하였을 때, 하이브 리드가 갖는 양의 표면전하가 음의 표면전하를 띠는 세균 에 더 잘 부착되어 세균 주변의 항균성을 갖는 추출물의 농도를 높여줌으로써 추출물만 처리할 때보다 금속이중 층수산화물에 담지하여 처리할 때 항균성능의 향상을 가 져옴을 확인하였다. 따라서, 본 연구를 통하여 금속이중 층수산화물의 재건법을 이용한 천연추출물의 항균소재 화의 역할과 잠재력이 있음을 확인할 수 있었다.

\section{참고문헌}

1. J.-H. Choy, S.-J. Choi, J.-M. Oh, T. Park, Clay minerals and layered double hydroxides for novel biological applications. Applied Clay Science 2007, 36 (1-3), 122-132.

2.E. Kanezaki, Direct Observation of a Metastable Solid Phase of $\mathrm{Mg} / \mathrm{Al} / \mathrm{CO} 3$-Layered Double Hydroxide by Means of High Temperature in S itu Powder XRD and DTA/TG. Inorganic Chemistry 1998, 37 (10), 25882590.

3. V. Rives, S. Kannan, Layered double hydroxides with the hydrotalcite-type structure containing $\mathrm{Cu} 2+$, $\mathrm{Ni2}+$ and Al3+. Journal of Materials Chemistry 2000, 10 (2), 489-495.

4. F. Cavani, F. Trifiro, A. Vaccari, Hydrotalcite-type anionic clays: Preparation, properties and applications.
Catalysis today 1991, 11 (2), 173-301.

5. V. Rives, Layered double hydroxides: present and future. Nova Publishers: 2001.

6. S. P. Newman, W. Jones, Synthesis, characterization and applications of layered double hydroxides containing organic guests. New Journal of Chemistry 1998, 22 (2), 105-115.

7. J. W. Boclair, P. S. Braterman, Layered double hydroxide stability. 1. Relative stabilities of layered double hydroxides and their simple counterparts. Chemistry of Materials 1999, 11 (2), 298-302.

8. M. Badreddine, A. Legrouri, A. Barroug, A. D. Roy, J. Besse, Ion exchange of different phosphate ions into the zinc-aluminium-chloride layered double hydroxide. Materials Letters 1999, 38 (6), 391-395.

9. M. Meyn, K. Beneke, G. Lagaly, Anion-exchange reactions of layered double hydroxides. Inorganic Chemistry 1990, 29 (26), 5201-5207.

10. E. D. Dimotakis, T. J. Pinnavaia, New route to layered double hydroxides intercalated by organic anions: precursors to polyoxometalate-pillared derivatives. Inorganic Chemistry 1990, 29 (13), 23932394.

11. S. Carlino, The intercalation of carboxylic acids into layered double hydroxides: a critical evaluation and review of the different methods. Solid State Ionics 1997, 98 (1-2), 73-84.

12. Q. Huang, J. Zhao, M. Liu, J. Chen, X. Zhu, T. Wu, J. Tian, Y. Wen, X. Zhang, Y. Wei, Preparation of polyethylene polyamine@ tannic acid encapsulated MgAl-layered double hydroxide for the efficient removal of copper (II) ions from aqueous solution. Journal of the Taiwan Institute of Chemical Engineers 2018, 82, 92-101.

13. H. Kopka, K. Beneke, G. Lagaly, Anionic surfactants between double metal hydroxide layers. Journal of Colloid and Interface Science 1988, 123 (2), 427-436.

14. J.-M. Oh, M. Park, S. - T. Kim, J.-Y. Jung, Y. - G. Kang, J.-H. Choy, Efficient delivery of anticancer drug MTX through MTX-LDH nanohybrid system. Journal of Physics and Chemistry of Solids 2006, 67 (5-6), 1024-1027.

15. S. H. Hwang, Y. S. Han, J. H. Choe, Intercalation of functional organic molecules with pharmaceutical, cosmeceutical and nutraceutical functions into layered double hydroxides and zinc basic salts. Bulletin of the Korean Chemical Society 2001, 22 (9), 1019-1022.

16. H. Nakayama, N. Wada, M. Tsuhako, Intercalation 
of amino acids and peptides into $\mathrm{Mg}-\mathrm{Al}$ layered double hydroxide by reconstruction method. International journal of pharmaceutics 2004, 269 (2), 469-478.

17. F. Leroux, J.-P. Besse, Polymer interleaved layered double hydroxide: a new emerging class of nanocomposites. Chemistry of Materials 2001, 13 (10), 3507-3515.

18. J. H. Choy, S. Y. Kwak, Y. J. Jeong, J. S. Park, Inorganic layered double hydroxides as nonviral vectors. Angewandte Chemie International Edition 2000, 39 (22), 4041-4045.

19. V. Rives, Characterisation of layered double hydroxides and their decomposition products. Materials Chemistry and Physics 2002, 75 (1-3), $19-25$.

20. F. R. Costa, U. Wagenknecht, G. Heinrich, LDPE/ $\mathrm{Mg}-\mathrm{Al}$ layered double hydroxide nanocomposite: thermal and flammability properties. Polymer Degradation and Stability 2007, 92 (10), 1813-1823.

21. M. -A. Thyveetil, P. V. Coveney, H. C. Greenwell, J. L. Suter, Computer simulation study of the structural stability and materials properties of DNA-intercalated layered double hydroxides. Journal of the American Chemical Society 2008, 130 (14), 4742-4756.

22. J.-H. Choy, S.-Y. Kwak, J.-S. Park, Y.-J. Jeong, J. Portier, Intercalative nanohybrids of nucleoside monophosphates and DNA in layered metal hydroxide. Journal of the American Chemical Society 1999, 121 (6), 1399-1400.

23. J.-M. Oh, T. T. Biswick, J.-H. Choy, Layered nanomaterials for green materials. Journal of Materials Chemistry 2009, 19 (17), 2553-2563.

24. J.-M. Oh, S.-Y. Kwak, J. -H. Choy, Intracrystalline structure of DNA molecules stabilized in the layered double hydroxide. Journal of Physics and Chemistry of Solids 2006, 67 (5-6), 1028-1031.

25. S. He, Z. An, M. Wei, D. G. Evans, X. Duan, Layered double hydroxide-based catalysts: nanostructure design and catalytic performance. Chemical Communications 2013, 49 (53), 5912-5920.

26. G. Fan, F. Li, D. G. Evans, X. Duan, Catalytic applications of layered double hydroxides: recent advances and perspectives. Chemical Society Reviews 2014, 43 (20), 7040-7066.

27. L. Zou, X. Xiang, J. Fan, F. Li, Single-source precursor to complex metal oxide monoliths with tunable microstructures and properties: the case of
$\mathrm{Mg}$-containing materials. Chemistry of Materials 2007, 19 (26), 6518-6527.

28. X. Xiang, H. I. Hima, H. Wang, F. Li, Facile synthesis and catalytic properties of nickel-based mixed-metal oxides with mesopore networks from a novel hybrid composite precursor. Chemistry of Materials 2007, 20 (3), 1173-1182.

29. X. Kong, X. Rao, J. Han, M. Wei, X. Duan, Layerby-layer assembly of bi-protein/layered double hydroxide ultrathin film and its electrocatalytic behavior for catechol. Biosensors and Bioelectronics 2010, 26 (2), 549-554.

30. H. -J. Kim, G. J. Lee, A. -J. Choi, T. - H. Kim, T. - i. Kim, J.-M. Oh, Layered double hydroxide nanomaterials encapsulating Angelica gigas Nakai extract for potential anticancer nanomedicine. Frontiers in pharmacology 2018, 9, 723.

31. K. Nejati, Z. Rezvani, M. Mansurfar, A. Mirzaee, M. Mahkam, Adsorption of metanil yellow azoic dye from aqueous solution onto $\mathrm{Mg}-\mathrm{Fe}-\mathrm{NO}_{3}$ layered double hydroxide. Zeitschrift füranorganische undallgemeine Chemie 2011, 637 (11), 1573-1579.

32. S. Casenave, H. Martinez, C. Guimon, A. Auroux, V. Hulea, A. Cordoneanu, E. Dumitriu, Acid-base properties of $\mathrm{Mg}-\mathrm{Ni}-\mathrm{Al}$ mixed oxides using $\mathrm{LDH}$ as precursors. Thermochimica Acta 2001, 379 (1-2), 85-93.

33. M. R. Weir, R. A. Kydd, Synthesis of heteropolyoxometalate-pillared $\mathrm{Mg} / \mathrm{Al}, \mathrm{Mg} / \mathrm{Ga}$, and $\mathrm{Zn} / \mathrm{Al}$ layered double hydroxides via $\mathrm{LDH}$ - hydroxide precursors. Inorganic chemistry 1998, 37 (21), 56195624.

34. D. Tichit, M. N. Bennani, F. Figueras, R. Tessier, J. Kervennal, Aldol condensation of acetone over layered double hydroxides of the meixnerite type. Applied Clay Science 1998, 13 (5-6), 401-415.

35. A. Marchi, C. Apestegu 1 a, Impregnation-induced memory effect of thermally activated layered double hydroxides. Applied Clay Science 1998, 13 (1), 35-48.

36. L. Lv, J. He, M. Wei, D. Evans, X. Duan, Factors influencing the removal of fluoride from aqueous solution by calcined $\mathrm{Mg}-\mathrm{Al}-\mathrm{CO}_{3}$ layered double hydroxides. Journal of Hazardous Materials 2006, 133 (1-3), 119-128.

37. T. Hibino, A. Tsunashima, Characterization of repeatedly reconstructed $\mathrm{Mg}-\mathrm{Al}$ hydrotalcite-like compounds: gradual segregation of aluminum from the structure. Chemistry of Materials 1998, 10 (12), 
4055-4061.

38. J.-M. Oh, S. - H. Hwang, J. - H. Choy, The effect of synthetic conditions on tailoring the size of hydrotalcite particles. Solid State Ionics 2002, 151 (1-4), 285-291.

39. J.-Y. Lee, G. -H. Gwak, H.-M. Kim, T. -i. Kim, G. J. Lee, J.-M. Oh, Synthesis of hydrotalcite type layered double hydroxide with various $\mathrm{Mg} / \mathrm{Al}$ ratio and surface charge under controlled reaction condition. Applied Clay Science 2016, 134, 44-49.

40. V. R. Constantino, T. J. Pinnavaia, Basic properties of Mg2+ 1-xAl3+ x layered double hydroxides intercalated by carbonate, hydroxide, chloride, and sulfate anions. Inorganic Chemistry 1995, 34 (4), 883-892.

41. V. R. Constantino, T. J. Pinnavaia, Structurereactivity relationships for basic catalysts derived from a $\mathrm{Mg}^{2+} / \mathrm{Al}^{3+} / \mathrm{CO}_{3}{ }^{2-}$ layered double hydroxide. Catalysis letters 1994, 23 (3-4), 361-367.

42. S. Aisawa, H. Hirahara, H. Uchiyama, S. Takahashi, E. Narita, Synthesis and thermal decomposition of $\mathrm{Mn}-\mathrm{Al}$ layered double hydroxides. Journal of Solid State Chemistry 2002, 167 (1), 152-159.
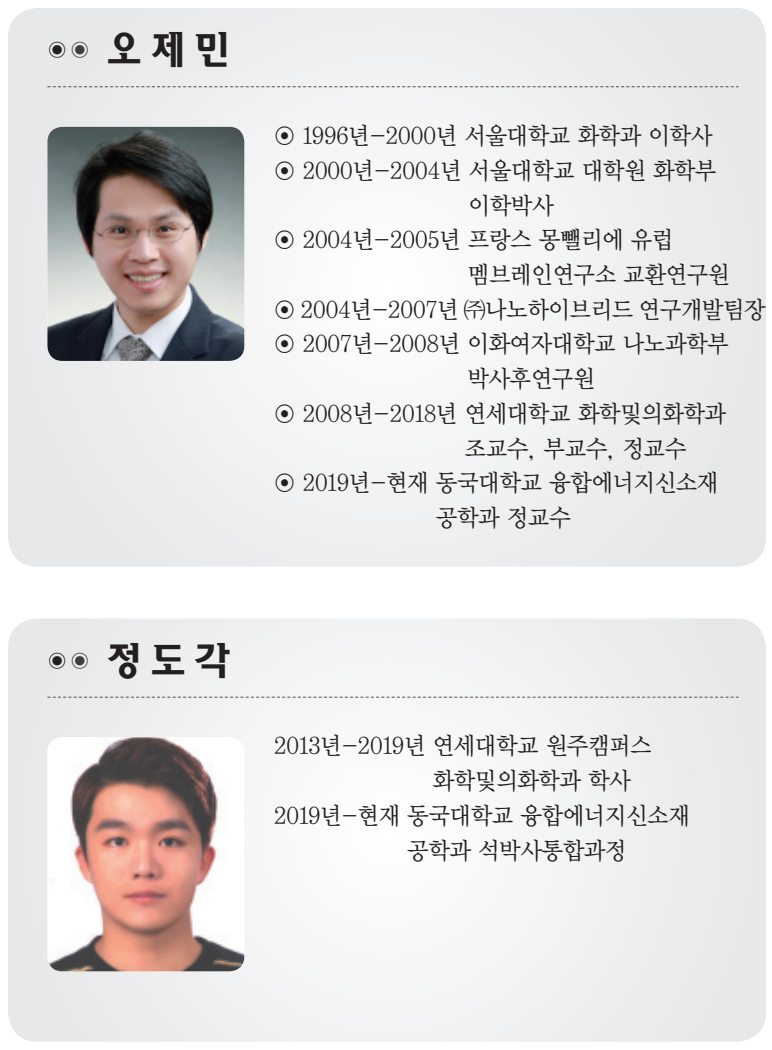

43. E. Kanezaki, Thermal behavior of the hydrotalcitelike layered structure of $\mathrm{Mg}$ and $\mathrm{Al}$-layered double hydroxides with interlayer carbonate by means of in situ powder HTXRD and DTA/TG. Solid State Ionics 1998, 106 (3-4), 279-284.

44. B. -K. Kim, G.-H. Gwak, T. Okada, J.-M. Oh, Effect of particle size and local disorder on specific surface area of layered double hydroxides upon calcination-reconstruction. Journal of Solid State Chemistry 2018, 263, 60-64.

45. T. - H. Kim, H.-J. Kim, A.-J. Choi, H.-J. Choi, J.-M. Oh, Hybridization Between natural extract of Angelica gigas Nakai and inorganic nanomaterial of layered double hydroxide via reconstruction reaction. Journal of nanoscience and nanotechnology 2016, 16 (1), 1138-1145.

46. H.-J. Kim, T. - H. Kim, H.-M. Kim, I. - K. Hong, E.-J. Kim, A.-J. Choi, H.-J. Choi, J.-M. Oh, Nano-biohybrids of engineered nanoclays and natural extract for antibacterial agents. Applied Clay Science 2016, 134, 19-25.

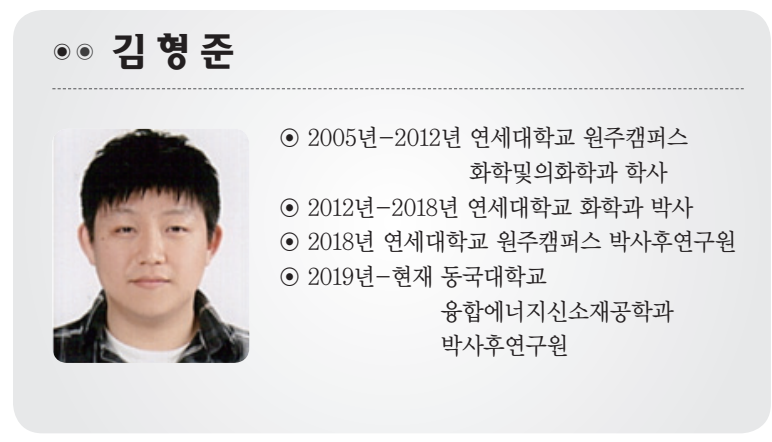

